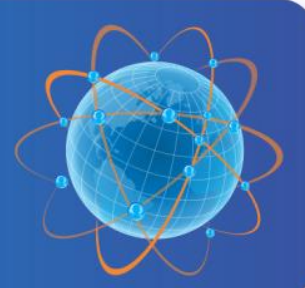

\title{
Resensi Buku : Liquid Surveillance : A Conversation
}

Authors : Budi Sutrisno

Published by : Departemen of Sociology, Faculty of Social and Political Science, Universitas Padjadjaran

Accepted : May 2017; Approved : June 2017

Sosiogobal: Jumal Pemikiran dan Penelitian Sosiologi is the Department of Sociology, Faculty of Social and Political Science, Universitas Padjadjaran flagship journal. The Sosioglobal journal founded in 2016 with the mission to publish original works of interest to the discipline of sociology in general, sociological thinking, new theoretical developments, results of research that enhance understanding of fundamental social processes, and methodological innovations. We are welcome a research article, working paper, theoretical/conceptual and methodological review to submit to our journal. In addition, we are accept relevant book review that currently publish and enrich sociological perspectives. Please submit article to http://jurnal.unpad.ac.id/sosioglobal 


\section{Resensi \\ Liquid Surveillance : A Conversation}

Budi Sutrisno $^{1}$

Prodi Sosiologi, Fakultas Ilmu Sosial dan Ilmu Politik, Univeritas Padjadjaran

budi.sutrisno@unpad.ac.id

\section{Bauman, Zygmunt and David Lyon. 2012. Liquid Surveillance: A Conversation. Cambridge: Polity Press.150 halaman}

Pengawasan (surveillance) terus mengalami perkembangan sebagaimana dunia yang erus mengalami transformasi dari generasi ke generasi. Pengawasan itu sendiri menjadi salah satu ciri mendasar didalam dunia modern. Masyarakat modern dikarakteristikan oleh kehidupannya yang begitu mengalir (fluid) yang kemudian memberikan gagasan bahwa kehidupan sedang berada pada tahap yang semakin cair (liquid) dimana segala sesuatunya selalu bergerak namun secara tidak pasti serta tidak kekal ikatannya. Saat ini, setiap warga negara, pekerja, konsumen bahkan turis setiap gerakannya selalu dilacak, diikuti dan dimonitor. Pengawasan tersebut juga mulai menyelinap ke tingkatan negara (liquid state). Buku yang berjudul Liquid Surveillance ini ditulis oleh dua orang pengarang yaitu Zygmunt Bauman dan David Lyon dengan tema yang berbeda. David Lyon memberikan kontribusi spesifik mengenai pengawasan (surveillance) dimana topik ini merupakan karyanya yang banyak diterbitkan diberbagai jurnal internasional. Sedangkan Zygmunt Bauman memberikan kontribusi mengenai konsep kecairan (liquidity). Bauman sendiri merupakan yang pertama mempopulerkan istilah liquidity yang merupakan aspek sentral didalam modernitas. Argumen yang dibangun adalah bahwa dunia ini bersifat kokoh dengan struktur yang padat tetapi kemudian mengalami perubahan bentuk dan menjadi semakin sulit untuk difahami. Bauman telah mengaplikasikan tesis ini di berbagai bidang seperti cinta, kehidupan, ketakutan dan masih banyak lagi. Didalam buku ini konsep liquidity kemudian diaplikasikan kedalam pengawasan (surveillance).

Tesis umum didalam buku ini adalah bahwa setiap individu kini dilacak (tracked) dan diawasi secara terus-menerus melalui teknologi baru yang belum pernah ada sebelumnya. Pengawasan tersebut kemudian menjadikan negara semakin cair (liquid) '...surveillance slips into a liquid state' (vi). Liquid surveillance digambarkan sebagai bentuk pengawasan yang lebih halus dibandingkan model pengawasan di masa lalu. Pengawasan saat ini tidak lagi selalu terkait dengan konsep "ruang" sebagaimana panopticon yang ditulis oleh 
Foucault. Saat ini konsep panopticon telah semakin berkembang ke arah post-panoptic yang bersifat lebih dinamis, bergerak (mobile) dengan mengandalkan jangkauan sinyal seluler. Dengan demikian, maka pengawasan menjadi lebih fleksibel, terlihat menyenangkan, menghibur dan kemudian menjadi konsumsi sehari-hari. Kini pengawasan dinikmati sebagai salah satu bentuk kesenangan dan tanpa disadari inilah bentuk pengawasan yang baru. Pengawasan post-panoptic ini kemudian semakin menyebar dengan cara yang tidak terbayangkan sebelumnya.

Pengaplikasian pertama dari teori liquid surveillance adalah didalam media sosial dan penggunaan drone. Keduanya dibahas secara bersamaan didalam satu bab karena kedua teknologi ini mengembangkan teknik pengawasan yang baru. Bauman berpendapat bahwa media sosial merupakan gabungan mimpi buruk panoptic dengan rasa takut ditinggalkan, diacuhkan, ditelantarkan atau disisihkan. Bauman mencontohkan bahwa seseorang bergabung di Facebook karena memiliki dua alasan yaitu : pertama, mereka merasa kesepian dan kedua, karena Facebook memberikan penyaluran (outlet) untuk meredakan ketegangan. David Lyon kemudian membawa pemikiran Simmel dan Foucault kedalam ruang diskusi mengenai kerahasiaan (privacy) di ruang media sosial. Simmel menekankan bahwa hubungan sosial antar aktor ditentukan oleh apa yang mereka ketahui tentang aktor lainnya. Dengan demikian maka tidak setiap orang dapat mengetahui rahasia orang lain. Sedangkan Foucault berargumen bahwa Facebook berfungsi sebagai ruang pengakuan dosa dimana kebenaran sejati (inner-truth) didalam diri individu akan terungkap. Masih menurut Foucault, Facebook secara dramatis mampu menggambarkan perasaan para individu yang bergabung didalamnya serta tanpa disadari mengambil peranan aktif didalam melakukan pengawasan terhadap diri sendiri (own surveillance). Bauman juga sependapat bahwa kita telah membangun sebuah masyarakat yang mengakui dosa sendiri (confessional society) ketika publisitas telah menjadi bagian dari kewajiban dan dipandang sebagai kebaikan. Berdasarkan karya sebelumnya mengenai masyarakat konsumsi (consumer society), Bauman lebih jauh berpendapat bahwa para pengguna media sosial pada dasarnya telah memperlakukan dirinya sendiri sebagai komoditas. Hal ini diperkuat dengan berfungsinya media sosial seperti Facebook sebagai sarana bersosialisasi untuk mempromosikan barang dagangan sekaligus menjadi komoditas itu sendiri. Mereka di saat yang sama berperan sebagai barang yang diperjualbelikan (merchandise) sekaligus juga agen yang memasarkannya atau menjadi barang (goods) sekaligus penjualnya (32). Facebook telah menjadikan diri kita sendiri 'sebagai produk yang mampu menarik perhatian pelanggan' 
(33) dan seluruh anggota masyarakat tanpa disadari telah dibentuk oleh permainan pasar. Bab ke-2 mendiskusikan tentang panopticon serta upaya untuk bergerak meninggalkan model pengawasan klasik tersebut. Meskipun David Lyon mengatakan bahwa metafora yang digunakan sangat brilian tetapi istilah panopticon hanya mendatangkan mimpi buruk didalam konsep pengawasan. Kedua pengarang tersebut kemudian mendorong agar bergerak kearah konsep pengawasan yang bersifat post-panoptic meskipun tetap tidak melupakan konsep panopticon itu sendiri. Panopticon disebutkan sebagai metafora yang masih bermanfaat mengenai bagaimana masyarakat modern mengatur sesuatu yang 'sulit dikendalikan' (56). Tetapi yang perlu dicatat pendorong utama didalam pengawasan modern bukanlah sebuah penjara. Sebagaimana Bauman menegaskan bahwa di masyarakat modern 'segala sesuatunya telah bergerak dari yang bersifat paksaan (enforcement) kepada godaan (temptation) dan bujukan (seduction) (57). Dalam hal ini, masyarakat yang diawasi tidak lagi merasa menjadi korban tetapi ikut aktif menjadi relawan didalamnya. Untuk bergerak melangkah dari konsep panopticon pengarang kemudian menggambarkan dengan tepat melalui konsep Bigo 'ban-opticon' dimana pengawasan dilakukan melalui pengunaan bahasa, arsitektur, hukum dan banyak lagi sehingga memberikan hasil akhir yang berbedabeda. Konsep pengawasan lainnya digagas oleh Mathiesen (1997) dengan menggunakan istilah synopticon. Jika dalam panopticon yang sedikit mengawasi yang banyak (many to few), maka dalam Synopticon yang banyak mengawasi yang sedikit (few to many) seperti penonton televisi menyaksikan tayangan olahraga, siaran berita dan selebritis.

Bab 3-7 membahas secara ringkas berbagai isu yang terkait dengan pengawasan. Dalam Bab 3, Bauman melihat bagaimana perang dilakukan dalam jarak jauh dengan menggunakan peralatan tempur berupa drone. Adanya jarak ini merupakan bagian dari proyek modernitas dari mulai program panopticon Bentham sampai ban berjalan Fordisme yang bertujuan untuk menghilangkan kekacauan dan aspek yang sulit diprediksi dari umat manusia yang tujuannya untuk menciptakan keteraturan. Mengenai masalah penjarakan (distancing) tersebut dijelaskan dalam bukunya mengenai Modernity and the Holocaust (1989).

Didalam Bab 4, pengarang mendiskusikan tentang konsep keamanan (security) dan ketidakamanan (insecurity). David Lyon mencatat bahwa pembenaran terhadap perlu adanya pengawasan seringkali mengatasnamakan keamanan. Tetapi hasil yang seringkali muncul justru ketidakamanan dan resiko (risk) yang dirasakan individu. Pemeriksaan menggunakan sinar $\mathrm{X}$ di bandara misalnya selalu mengatasnamakan keamanan tetapi disadari atau tidak 
justru menciptakan rasa tidak aman terhadap individu yang menjadi subjek dari perlakuan tersebut. Menurut Lyon, 'kita telah terjebak dalam upaya mencoba untuk tetap hidup bahagia meskipun diliputi rasa takut, tetapi setiap upaya tersebut justru memproduksi resiko dan ketakutan yang lebih banyak'. Dengan demikian dapat disimpulkan bahwa pencarian modern terhadap perdamaian abadi merupakan kepalsuan.

Pada Bab 5, pengarang mengalihkan fokus perhatiannya kepada berbagai media yang baru bermunculan serta konsumerisme yang prosesnya begitu cair. Lyon menduga bahwa konsumerisme saat ini telah menjadi subjek penting ketika membahas pengawasan modern sebagaimana kekuatan militer. Sedangkan Bauman menyatakan bahwa dalam masyarakat konsumtif semakin sedikit adanya keinginan untuk memenuhi kebutuhan (need) tetapi semakin banyak menciptakan hasrat (desire). Dengan demikian, menurut Bauman, masyarakat konsumtif akan terus-menerus menciptakan hasrat untuk selalu dipuaskan yang kemudian dikenal dengan istilah Scopophilia.

Pada dua bab terakhir, pengarang menutup diskusinya dengan bahasan mengenai agen, harapan, moralitas dan etika yang terkait dengan pengawasan. Kekhawatiran yang ada adalah bahwa teknologi dalam bidang pengawasan (surveillant technologies) akan berubah dengan sangat cepat sehingga sulit untuk diikuti. Hal ini berdasarkan beberapa contoh pengawasan mulai dari melihat individu sebagai tahanan penjara yang kemudian diikat oleh sistem birokrasi dan sekarang oleh telepon genggam. Kondisi demikian yang kemudian memunculkan pertanyaan, dimanakah agen? masih adakan harapan untuk melepaskan diri dari berbagai pengawasan tersebut?. Buku ini diakhiri dengan catatan dari kedua pengarang dimana Bauman tampak kurang optimistis dibandingkan David Lyon.

Kesimpulannya, meskipun format dari buku ini berupa percakapan santai dan ringkas namun isinya tetap provokatif. Secara umum pembahasan buku ini telah bergerak melampaui isuisu sejenis di masa lalu namun sayangnya tidak tuntas. Pengarang membahas mengenai model pengawasan panopticon dimana yang sedikit mengawasi yang banyak dan kemudian bergerak ke model synopticon yaitu yang banyak mengawasi yang banyak. Kelemahannya pengarang tidak membahas mengenai yang banyak mengawasi yang banyak seperti yang terjadi di media sosial. Hal ini menjadi penting karena model panopticon dan synopticon kini menjadi berkurang relevansinya didalam mengkaji konsep massa yang cair (liquid mass) seperti yang terdapat didalam media sosial. 